\title{
PEDAGOGICAL CONDITIONS OF TRAINING OF FUTURE TEACHERS OF PRESCHOOL EDUCATION INSTITUTIONS FOR IMPLEMENTATION OF INTERACTIVE TECHNOLOGIES IN INCLUSION
}

\author{
Liubov Tokar \\ Lecturer, Vinnytsia Humanitarian and Pedagogical College, \\ Postgraduate Student, Vinnytsia Mykhailo Kotsiubynskyi \\ State Pedagogical University, Ukraine \\ e-mail: tokarluba80@gmail.com,orcid.org/0000-0003-4817-0909
}

\section{Marcin Szwiec}

Ph.D., Polonia University in Czestochowa, Interdisciplinary Faculty, Poland e-mail: mszwiec@ap.edu.pl,orcid.org/0000-0002-9649-9154

\section{Summary}

The article highlights the main principles and theoretical aspects of forming the readiness of future teachers of preschool education to implement interactive technologies in an inclusive educational environment. The topical problem of preschool education is revealed - ensuring equal rights and opportunities for children of early and preschool age who have disorders in psychophysical development in the system of modern preschool education.

The article presents an analysis of scientific literature on the problem of research; emphasizes the need to create appropriate pedagogical conditions for the preparation of future preschool education teachers to implement interactive technologies in an inclusive educational environment; identifies a number of pedagogical conditions that ensure the formation of the readiness of future educators for the organization of inclusive education in the process of professional training.

The indicators of formation of preschool educational teachers professional competence their work in educational institutions with children who have special needs are analyzed and determined.

Keywords: readiness, competence, self-improvement, self-development, children with special educational needs, psychophysical development disorders.

DOI https://doi.org/10.23856/4110

\section{Introduction}

The reform of the national education system that is currently taking place in Ukraine highlights the problems of training future teachers who are able to work in accordance with the new methodological guidelines outlined by the Concept of the New Ukrainian School. Among Hum, an inclusive education occupies a prominent place, and it is an educational paradigm based on the ideological principles of social inclusion, such as equality, accessibility, these are the fundamental imperatives of its functioning.

In recent years, the number of children with special educational needs has increased in different regions of the country. Accordingly, the number of specialized groups in preschool institutions has increased. That is view of this, there is an urgent need in Ukraine to reform the state policy in the field of education, special (inclusive) education in particular, and qualified teachers of preschool institutions who are able to work with children with special educational needs. 
Based on the above, we believe that a specialist in this field should have a deep level of knowledge on inclusive education, implementing the requirements for the humanization of special education, its social orientation and creating conditions for adaptation and integration of children with special educational needs into society.

Requirements for the preparation of future teachers of preschool education to implement interactive technologies in an inclusive educational environment require the introduction of a competency-based approach to educational work, which involves the introduction of new principles, methods, technologies and forms of educational work.

Thus, there is a need to form the training of future teachers of preschool education to implement interactive technologies in an inclusive educational environment.

The analysis of current research. Fundamental problems of the theory of vocational education are revealed in a number of studies (S. Arkhangelsky, I. Zyazyun, N. Kichuk, S. Goncharenko, O. Pekhota, O. Savchenko, V. Slastyonin). The study of the problem of forming a generation of people who think and act in an innovative way has always received due attention, in particular, to the following aspects: professional training of specialists in special education (V. Bondar, L. Vygotsky, S. Zabramna, N. Yeremenko, N. Puzanov, V. Sinyov, E. Sinyova, N. Stadnenko, L. Shipitsyna, etc.); theory of competence-oriented approach to learning (I. Zimnyaya, I. Zyazyun, N. Kuzmina, A. Markova, O. Savchenko, G. Tereshchuk, A. Khutorsky, etc.); formation and increase of professional competence of future teachers of preschool education institutions(G. Belenka, E. Panko, I. Bekh, O. Kononko, K. Krutiy, N. Gavrish, V. Slastyonin, V. Vedensky, I. Romanyuk, etc.); the essence of the terminological characteristics of the concept of "readiness" is covered in the works (L. Bozhovych, A. Derkach, M. Dyachenko, L. Kandybovych, V. Krutetsky, V. Tatenko, etc.); features of "readiness for professional activity" (G. Ball, E. Klimov, Y. Zavalevsky, S. Maksymenko, P. Perepylytsia, M. Smulson, P. Kharchenko, etc.).

Issues of application of interactive technologies in the work were studied by both foreign (V. Donham, L. Reynold, etc.) and domestic (I. Gladkikh, V. Gordin, O. Koroteeva, E. Mikhailov, L. Strutska, etc.) scientists.

Paying tribute to this research, it should be noted that little has been learned about such an aspect as the preparation of future teachers of preschool education to implement interactive technologies in an inclusive educational environment.

The purpose of the article is to identify the basic principles of forming pedagogical conditions for preparing future teachers of preschool education for professional activities, the essence of competence and structural activities of teachers of preschool education to work with children in an inclusive educational environment of preschool education.

Research methods. We used a set of the following methods: analysis of psychological and pedagogical, scientific and methodological literature in the system of pedagogical education to clarify the state of the outlined problem; systematization, synthesis, generalization, which made it possible to reveal the essence of the problem, to single out the main components of the readiness of future teachers of preschool institutions for professional activity in line with the outlined problem; substantiation of pedagogical conditions for the formation of training of future teachers of preschool education in an inclusive educational environment with the use of interactive technologies. 


\section{Pedagogical conditions for training future teachers of preschool education}

First of all, let's define the concept of "pedagogical conditions". Condition is traditionally understood as a philosophical category that expresses the relationship of an object to the environment, without which it can not exist, moreover, the conditions are the environment, the environment in which the phenomenon occurs, exists and develops (Ushynskyi, K. D., 1963).

S. Ozhegov in his dictionary gives the following definition of the condition: "This is a circumstance on which something depends; the situation in which something happens; data, requirements that should be hidden" (Ozhegov S.I., 1990: 729).

A. Nine under pedagogical conditions understands a set of objective possibilities, content, forms, methods, pedagogical techniques and material-spatial environment aimed at solving the tasks set in the study (Najn A.Ya., 1995).

\section{Training of future teachers of preschool institutions}

The problem of "readiness" in pedagogy is considered from different positions. It should be noted that K. Ushinsky (Ushynskyi, K. D., 1988) was one of the first in domestic pedagogy to raise the issue of teacher training.

In the 70s of XX century. I. Bekh, K. Durai, M. Dyachenko, V. Slastyonin, and others studied the problem of a person's readiness for activity in pedagogy.

In the second half of the twentieth century, the concept of "readiness" was mostly defined as a selective, predictable activity of the individual at the stage of its preparation for activity; such activity arises as a result of delineation of the professional purpose on the basis of perceived needs and motives (Diachenko, M. I., \& Kandybovich, L. A. (1976).

The concept of readiness for a particular type of activity, defined by S. Maksymenko, O. Pelekh, is interpreted as "purposeful expression of personality, including its beliefs, views, motives, feelings, volitional and intellectual qualities, knowledge, skills, abilities, guidelines" (Maksymenko, SD, \& Pelekh, OM (1994).

L. Gekalo notes that a modern teacher is a fundamentally educated person, able to flexibly restructure the direction and content of their professional activities, who independently works on their own development, raising educational and cultural levels, is able to independently acquire the necessary knowledge, skills and abilities. thinks, has a stable system of motives and needs of socialization, is able to act actively and creatively. He must be able to teach children to creatively acquire knowledge, apply them in specific educational and life situations, critically comprehend the information obtained, master the skills of self-development, self-analysis, selfcontrol and self-assessment.

A characteristic feature of his professional consciousness should be the focus of thinking on pedagogical problems, the vision of the pedagogical process as a holistic phenomenon, the central place in which belongs to the child's personality (Hutsan, T. H. (n.d.).

In line with our study, we note that the activity of a teacher of preschool education, aimed at the ability to work with children with special educational needs in an inclusive educational environment of preschool education, does not have a clear algorithm for solving, so it is necessary that in professional activities he was able to self-development, to constant creative search, to the manifestation of activity, humanism, because the ability of the individual to develop, self-organization, self-regulation of himself as a subject of activity is explained by his professional competence.

The readiness of a preschool teacher to work with children with special educational needs, and, consequently, his competence should be manifested: in the skill of his work; in the ability to organize educational, correctional and developmental work with children with special educational needs in nosology (impaired vision, hearing, speech, mental development, musculoskeletal system); create a positive emotional attitude to classes, various activities; ability 
to choose appropriate methods of educational influence on children; it is quite responsible to conduct educational work among parents (or persons replacing them) raising children with special educational needs.

In this context, we note that the education of children with special educational needs in specialized groups of preschool education involves improving the inclusive educational environment, where the teacher of preschool education is fully open to communication, where the rights and needs of children, their abilities and prospects to be successful. It is the preschool teacher and his / her competence that play an important role in teaching children with special educational needs.

\section{Pedagogical conditions for training future teachers of preschool education institutions}

Based on the results of the analysis of scientific literature and practice of training educators, we have identified a number of pedagogical conditions that ensure the formation of readiness of future educators for inclusive education in the process of training: model of training future teachers to implement interactive technologies in inclusive education; development of positive motivation of future teachers of preschool education institutions to use interactive technologies in an inclusive educational environment; selection and implementation of the content of disciplines of the psychological and pedagogical cycle in the special course "Organization of educational work with preschool children with special educational needs"; combination of theoretical and practical training by ensuring the succession of stages (information-oriented, quasi-professional and activity.

5. The model of training future teachers of preschool education institutions to implement interactive technologies in an inclusive educational environment is a deeply individual connection that does not involve patterns and stereotypes

Modeling is the main category of the theory of cognition, on which theoretical and experimental methods of scientific research are based. The development of the model is due to the need to improve the process of training future teachers of preschool education to implement interactive technologies in an inclusive educational environment. Our proposed model of the pedagogical system allows us to assess the connections and relationships between different factors influencing it and to identify on this basis psychological and pedagogical patterns (Miheev V.I., 2006).

Concluding the model of future teachers of preschool education to implement interactive technologies in an inclusive educational environment, we sought to make it informative, easy to use, consistent with other pedagogical objects of the system, to identify mechanisms for managing this process through its impact on its components (Lodatko Ye.O, 2010).

The main structural components of the developed model are: the purpose and tasks, conditions of its successful realization; principles, stages and ways of preparing students, levels of student achievement. All these components are aimed at creating a system for the formation of inclusive competence of future teachers. Among the main approaches to the development of this model were used: systemic, integrative, personality-oriented, activity, cultural.

During the practical activities students were offered interactive technologies with a wide range of opportunities: discussions "For and against", "Qualities of a competent specialist", game methods: "Facts, only facts", "Mirror", method "case study". Interactive technologies provide an opportunity for a comprehensive impact on the intellectual, emotional and motivational sphere of the individual. All kinds of interactive technologies activate cognitive processes, increase the speed of collecting and processing information, develop the ability to analyze problems, form the basis for competent decision-making. Information and communication technologies are widely used. 


\section{Development of positive motivation of future teachers of preschool education institutions to use interactive technologies in an inclusive educational environment}

The second pedagogical condition for the effective implementation of the process of forming the professional readiness of future teachers of preschool education is to use the potential of the content of pedagogical disciplines to form a positive motivation for inclusive education, knowledge of the development, training and education of different categories of children with special educational needs. activities of a teacher of a preschool institution in the conditions of inclusive education.

\section{Selection and implementation of the content of disciplines of the psychological and pedagogical cycle in the special course «Organization of educational work with preschool children with special educational needs»}

We analyzed the curricula and programs of disciplines of the psychological and pedagogical cycle, studied in a pedagogical institution of higher education within the state standards of higher professional education, to identify potential opportunities to influence the readiness of future teachers of preschool education to implement interactive technologies in an inclusive educational environment. Thus, the implementation of the condition - synthesizing the content of disciplines of the psychological and pedagogical cycle in the special course «Organization of educational work with preschool children with special educational needs», contributed to the effectiveness of training students to work with preschool children in inclusion. Under this condition, it was planned to resolve the contradictions between the complexity of the professional activities of teachers of preschool education and the insufficient level of knowledge and skills to work in an inclusive environment, taking into account its specifics and psychological and pedagogical characteristics of preschool children. An important role in preparing future teachers of preschool institutions for the implementation of interactive technologies in an inclusive educational environment belonged to pedagogical practice. During the psychological and pedagogical practice, students conducted developmental and educational work with preschool children, taking into account their age and individual characteristics; conducted psychological and pedagogical observation of the child's development at an early age; determined the level of development; compiled psychological and pedagogical characteristics of the child, analyzed the process of adaptation of young children to the conditions of preschool education (developed diagnostics of the level of development of young children, the formation of mental processes, various activities); analyzed the classes of teachers of preschool education in the conditions of inclusion; developed and conducted fragments of classes).

\section{Combination of theoretical and practical training by ensuring the succession of stages (information-oriented, quasi-professional and activity)}

The pedagogical condition that contributes to the effective implementation of the process of forming inclusive competence of future teachers of preschool education in the process of professional training is to ensure the continuity of stages of formation of readiness of future teachers of preschool education, development and application of key competencies in practical and research activities.

As a result, we have identified indicators of professional competence of teachers of preschool education institutions working with children with special educational needs: the 
ability to social interaction, cooperation and conflict resolution in the social and professional spheres, tolerance, social mobility; ability to use knowledge in educational and professional activities; ability to realize the social significance of their profession, to be motivated to perform professional activities; readiness to organize an inclusive environment, its methodological support and correctional and rehabilitation work for the successful rehabilitation of children with special educational needs; readiness to interact with the families of children with special educational needs for the implementation of technological support; ability to analyze the basic technologies of psychological and pedagogical support of the correctional process. The identified indicators of the formation of professional competence, of course, can not claim to be exhaustive. They can be considered conditional, because the process of formation of professional competence is continuous, so it is difficult to predict the ratio of different components of the level of its formation, their manifestation and invisible changes.

9. Conclusions and prospects for further scientific research

Thus, the pedagogical conditions for the training of future teachers of preschool education institutions are implemented by mastering various forms and methods of active learning, which helps teachers to quickly gain professional experience, the source of which is pedagogical activity, meaningful in terms of essence goals and, technologies of a preschool education teacher. The use of interactive technologies in combination with information and communication technologies provide an opportunity in an accessible form to expand, systematize, generalize the competencies of teachers of preschool education on the peculiarities of working with children in an inclusive educational environment of preschool education. Skills that optimize the sociopedagogical activities of the teacher of preschool education, provide more opportunities to take into account the various problems of students with special educational needs, thereby ensuring their inclusion in the social environment, creating conditions for comfortable development of students, and in the further self-development of their full-fledged socialization.

Analysis of the problem of training future teachers of preschool education in an inclusive educational environment showed the need for future research to study and clarify the features of the use of interactive technologies in the methodological work of the institution for effective psychological and pedagogical and correctional rehabilitation of children, professional competence of teachers in in the field of education of children with special educational needs.

Given the importance of forming the readiness of teachers of preschool education to work with children in an inclusive educational environment of preschool education and the fact that in Ukraine this concept is underused and insufficiently researched, there is a prospect of further deeper and more detailed studies of this socio-psychological and pedagogical phenomenon, practical ways of its formation.

\section{References}

Hutsan, T. H. (n.d.) Naukovo-teoretychnyi analiz hotovnosti maibutnoho vchytelia ekonomiky do profilnoho navchannia starshoklasnykiv [Scientific and theoretical analysis of the readiness of the future teacher of the economy for the profile education of high school students]. Retrieved from http://intkonf.org/gutsan-tg-naukovo-teoretichniy-analiz-gotovnosti-maybutnogo-vchitelya-ekonomiki-do-profilnogo-navchannya-starshoklasnikiv/. [in Ukrainian].

Diachenko, M. I., \& Kandybovich, L. A. (1976). Psikhologicheskie problemy gotovnosti k deiatelnosti [Psychological problems of readiness for activity]. Minsk: BGU. [in Russian].

Lodatko Ye.O. Modeliuvannia v pedahohitsi: tochky vidliku / Ye.O. Lodatko // E-zhurnal «Pedahohichna nauka: istoriia, teoriia, praktyka, tendentsii rozvytku» - 2010. - Vypusk 
№ 1 - [Elektronnyi resurs]. - Rezhym dostupu:http://intellectinvest.org.ua/pedagog_editions_ emagazine_pedagogical_science_vypuski_n1_2010_st_2\%.[in Ukrainian].

Maksymenko, S. D., \& Pelekh, O.M. (1994). Fakhivtsia potribno modeliuvaty (Naukovi osnovy hotovnosti vypusknyka pedvuzu do pedahohichnoi diialnosti) [The specialist needs to be modeled (Scientific fundamentals of readiness of the graduate of the pedagogy to pedagogical activity)]. Ridna Shkola, 3-4, 70. [in Ukrainian].

Miheev V.I. Modelirovanie i metody teorii izmerenij v pedagogike [tekst]: - 3-e izd., stereotip. I V. I. Miheev. - M. : KomKniga, 2006. - S. 8. [in Russian].

Najn A.Ya. O metodologicheskom apparate dissertacionnyh issledovanij. Pedagogika, 1995. № 5. S. 44-49. [in Russian].

Ozhegov S.I. Slovar russkogo yazyka / pod red. N. Yu. Shvedovoj. Moskva: Rus. yaz., 1990. 921 s. [in Russian].

Ushynskyi K. D. Vybranipedahohichni tvory. Kyiv: Rad. shkola, 1963. T. 1. 467 s. [in Ukrainian]. Ushynskyi, K. D. (1988). (Liudyna yak predmet vykhovannia. Sproba pedahohichnoi antropolohii. In K. D. Ushynskyi, Vybrani pedahohichi tvory: Vol. 1. Kyiv: Radianska shkola. [in Ukrainian]. 